CASE REPORT

\title{
Familial dysalbuminaemic hyperthyroxinaemia, a thyroid trap
}

\author{
P R Desai, A P Lipscomb, J Slater
}

Arch Dis Child 2004;89:1161-1162. doi: 10.1136/adc.2002.021709

$\mathrm{P}$ aediatricians are frequently asked to see children who cause concern because of their slow growth or development. In this situation, despite the absence of any specific abnormal signs, thyroid function tests are commonly requested. They are nearly always normal.

We describe three patients, where abnormal results led to erroneous treatment for thyrotoxicosis. These patients had a diagnosis of familial dysalbuminaemic hyperthyroxinaemia $(\mathrm{FDH})$, an interesting condition with euthyroid hyperthyroxinaemia where the patient is clinically euthyroid but has raised laboratory value of free thyroxine. ${ }^{1}$ Euthyroid hyperthyroxinaemia encompasses a broad range of conditions that can easily be misinterpreted as hyperthyroidism. ${ }^{2}$

\section{CASE 1}

A 7 year old girl referred to the hospital, was seen by general practitioner because of poor and abnormal thyroid function test results performed in primary care: total thyroxine $248 \mathrm{nmol} / \mathrm{l}$ (normal 80-150 nmol/1), free thyroxine $38 \mathrm{pmol} /$ $\mathrm{l}$ (normal 10-25 pmol/l), and TSH $0.94 \mathrm{mU} / \mathrm{l}$ (normal 0.4$4 \mathrm{mU} / \mathrm{l}$ ) (Bayer competitive assay for total and free thyroxine) (table 1).

Her pulse rate was 106 per minute but she had no other clinical features of thyrotoxicosis. Treatment was commenced with carbimazole $(30 \mathrm{mg}$ ) after discussion with the paediatric endocrinologist.

Eighteen months later, while on treatment, the thyroid function tests remained abnormal (total thyroxine $105 \mathrm{nmol} /$ $\mathrm{l}$, free thyroxine $28.6 \mathrm{pmol} / \mathrm{l}$, TSH $31.1 \mathrm{mU} / \mathrm{l}$ ). This prompted the paediatrician to start block and replace therapy with additional thyroxine.

Two years from diagnosis, despite euthyroid clinical status and normal growth, biochemical control was still not achieved. The total and free thyroxine were still raised. The local adult endocrinologist was asked to review her. He investigated her further (table 2) and was able to discontinue her antithyroid treatment without ill effects.

\section{CASE 2}

A 2 year old boy was investigated by his local hospital for failure to thrive. The thyroid function test results were abnormal (free thyroxine was $43.9 \mathrm{pmol} / \mathrm{l}$ and TSH was $4 \mathrm{mU} / \mathrm{l}$ (table 1). His resting pulse was recorded at 120 per minute.

Treatment was commenced with carbimazole. After six months the family moved and his care was transferred to our hospital.

On assessment in the clinic the parents reported no improvement since initiating treatment and he appeared clinically euthyroid. Following further endocrine investigations (table 2) including repeat thyroid function tests, carbimazole was discontinued.

\section{CASE 3}

A 34 year old male presented to his general practitioner with complaints of tremors, palpitations, and tiredness; he was known to suffer from chronic bipolar disorder. The general practitioner noticed tachycardia, but there was no goitre. However, the thyroid function tests were abnormal (thyroxine $196 \mathrm{nmol} / \mathrm{l}$, free thyroxine $44.5 \mathrm{pmol} / \mathrm{l}$, and TSH $1.27 \mathrm{mU} / \mathrm{l})$. With a diagnosis of thyrotoxicosis, carbimazole was commenced.

After six months of treatment total $\mathrm{T}_{4}$ was $148 \mathrm{nmol} / \mathrm{l}$ and TSH had increased to $12.88 \mathrm{mU} / \mathrm{l}$. Hence he was commenced on block and replace therapy with $25 \mu \mathrm{g}$ thyroxine.

There was no improvement in his biochemistry despite treatment for 15 months. He was referred to an endocrinologist who discontinued his treatment and investigated him further (table 2)

Table 1 Initial investigations and treatment

\begin{tabular}{|c|c|c|c|c|c|c|}
\hline & Age (y) & $\begin{array}{l}\text { TSH }(\mathrm{mU} / \mathrm{l}) \\
(\mathrm{N}=0.4-4)\end{array}$ & $\begin{array}{l}\text { Total } \mathrm{T}_{4}(\mathrm{nmol} / \mathrm{l}) \\
(\mathrm{N}=80-150)\end{array}$ & $\begin{array}{l}\text { Free } \mathrm{T}_{4}(\mathrm{pmol} / \mathrm{l}) \\
(\mathrm{N}=10-25)\end{array}$ & $\begin{array}{l}\text { Free } \mathrm{T}_{4} \text { on } \\
\text { treatment }\end{array}$ & $\begin{array}{l}\text { Duration of } \\
\text { treatment }\end{array}$ \\
\hline Case 1 & 8 & 2.5 & 248 & 31.5 & 62.4 & $2 y$ \\
\hline Case 2 & 7 & 4.0 & 238 & 43.9 & 40.4 & $6 \mathrm{mth}$ \\
\hline Case 3 & 33 & 1.27 & 196 & 44.4 & 40.8 & 1 y $3 \mathrm{mth}$ \\
\hline
\end{tabular}

$\mathrm{N}$, normal; $\mathrm{T}_{4}$, thyroxine; $\mathrm{TSH}$, thyroid stimulating hormone.

Table 2 Further investigations

\begin{tabular}{lllll}
\hline & $\begin{array}{l}\text { Free } \mathrm{T}_{\mathbf{4}} \text { (pmol/l) } \\
\text { Equilibrium dialysis }\end{array}$ & TBG & Alpha subunit TSH & Antibodies $\mathrm{T}_{\mathbf{4}} / \mathrm{T}_{\mathbf{3}}$ \\
\hline Case 1 & 23.4 (normal) & & Normal & Negative \\
Case 2 & 19.6 & Normal & & Negative \\
Case 3 & 18.6 & & Negative & Positive \\
\hline
\end{tabular}

TBG, thyroid binding globulin; $T_{4}$, thyroxine; $T_{3}$, triiodothyronine; $T S H$, thyroid stimulating hormone; $F D H$, familial dysalbuminaemic hyperthyroxinaemia. 


\section{Summary and key points}

- FDH patients may be mistakenly thought to be thyrotoxic and hence subjected to treatment, which is often unnecessary.

- To avoid this trap: on finding a patient with high free thyroxine, resist the temptation to treat unless the clinical and biochemical picture is consistent. We would recommend measurement of basal TSH using a highly sensitive assay, which will be normal if the patient has FDH; this confirms that the patient is in the euthyroid state and prevents unnecessary treatment.

- Clinicians should be aware of the conditions causing euthyroid hyperthyroxinaemia.

- When FDH has been diagnosed, screening of the patient's immediate family should be carried out, to avoid fruitless diagnostic studies and unnecessary treatment.

\section{FURTHER INVESTIGATIONS}

Because of diagnostic uncertainty the patients' serum was further assessed by thyroid two step assay (equilibrium dialysis). This was normal in all the patients. In this method free thyroxine is first separated from binding proteins and then assayed independently, thus excluding protein interference. $^{3}$

Tests for thyroid antibodies were negative in all cases.

FDH screen, a protein electrophoresis ${ }^{4}$ looking for abnormal albumin, was positive in all cases.

All patients received treatment for a duration of 6 months to 2 years, fortunately without any ill effects. The patients remained well off treatment. Careful follow up confirmed normal growth of the two children.

\section{DISCUSSION}

Normally $99.9 \%$ of thyroxine transported in blood is in the bound form. Seventy five per cent is bound to thyroid binding globulin (high affinity binding); the remainder is bound to pre-albumin (10-15\%) and albumin (10-15\%) (low affinity binding). ${ }^{13}$ In FDH, however, up to $30 \%$ of thyroxine is bound to abnormal albumin while the unbound free concentration remains normal. ${ }^{1356}$

Due to the development of single step techniques (analogue free thyroxine assays), measurement of free thyroxine is easy and is widely used as the first line test of thyroid function. Thyroid assay by analogue free thyroxine is based on the assumption that only $10 \%$ of the thyroxine in plasma is albumin bound. ${ }^{5}$ In FDH, the analogue employed in "analogue free thyroxine assays" shows high affinity for the mutant albumin; spuriously high free thyroxine levels are therefore produced by this method, whereas free thyroxine is normal in the patients. This binding protein interference is excluded in equilibrium dialysis, a two step method, in which free hormone is extracted from serum first and then analysed independently. ${ }^{7}$

In 1979 Henneman and Lee first described FDH, an autosomal dominant condition characterised by strikingly increased total thyroxine and free thyroxine, and normal TSH; patients are clinically euthyroid. ${ }^{89}$

In FDH, binding to albumin is 30\% (normally $10 \%$ ). Hence albumin becomes the main binding protein, especially as it is available in a large quantity compared to TBG, but binding of thyroxine to triiodothyronine is normal. ${ }^{1361011}$ In 1994, Peterson et al showed that the increased binding is due to substitution of arginine to histidine at position 218 on the albumin protein. ${ }^{12}$
The incidence of FDH is not known, mainly due to the fact that the condition is diagnosed by chance when thyroid function tests are ordered. ${ }^{1}$ Patients who are anxious when examined in the clinic may show signs such as tachycardia and sweating. The physician can misinterpret these signs as features of thyrotoxicosis, especially since he may have been primed by knowledge of the abnormal thyroid blood results. ${ }^{1}$

Clinicians should be aware of the technical limitations of conventional one step thyroid assays and should be suspicious of diagnosing hyperthyroidism when there are no eye signs or goitre, and most importantly when the TSH concentration is in the normal range. ' Whenever a result for free thyroxine concentration seems inappropriate to the patient's clinical state, the clinician should question the "clinical chemistry" results, particularly the analogue free thyroxine assays. Euthyroid hyperthyroxinaemia (high total and free thyroxine with a normal TSH) should be suspected in these situations to prevent inappropriate therapy. ${ }^{139}$

The conditions which can cause this are:

- Increased thyroid binding globulin

- Familial dysalbuminaemic hyperthyroxinaemia

- Thyroid antibodies

- Resistance to thyroid hormones: central and peripheral

- Drugs: amiodarone prevents peripheral conversion of thyroxine to triiodothyronine

- Acute psychiatric illness.

We end this paper with classical a quote from undergraduate teaching: "Treat the patient, not the laboratory report".

\section{Authors' affiliations \\ P R Desai, A P Lipscomb, St John's Hospital, Chelmsford, UK J Slater, Broomfield Hospital, UK}

Correspondence to: Dr P R Desai, St John's Hospital, Chelmsford CM2 9BG, UK; prpravin@yahoo.com

Accepted 3 March 2004

\section{REFERENCES}

1 Jensen IW, Faber J. Familial dysalbuminaemic hyperthyroxinaemia: a review. J R Soc Med 1988;81:34-7.

2 Farror C, Wellby ML, Beng C. Familial dysalbuminaemic hyperthyroxinaemia and other causes of euthyroid hyperthyroxinaemia. J R Soc Med 1987;80:750-2.

3 Stewart MF, Ratcliffe WA, Roberts I. Thyroid function tests in patients with familial dysalbuminaemic hyperthyroxinaemia (FDH). Ann Clin Biochem 1986;23(pt 1):59-64.

4 Flechner I, Aranoff G, Reifen R, et al. Detection of albumin binding abnormalities in sera of patients with familial dysalbuminaemic hyperthyroxinaemia using isoelectric focusing. Endocr Res 1992;18:229-40.

5 Wood DF, Zalin AM, Ratcliffe WA, et al. Elevation of free thyroxine measurements in patients without thyrotoxicosis. Q J Med 1987;65:863-70.

6 Fleming SJ, Applegate GF, Beardwell CG. Familial dysalbuminaemic hyperthyroxinaemia. Postgrad Med J 1987;63:273-5.

7 Monson JR. Assessment of thyroid function. In: Grossman A, ed. Clinical endocrinology, 2nd edn. Oxford: Blackwell Science.

8 Henneman G, Docter R, Kreening EP, et al. Raised total thyroxine and free thyroxine index but normal free thyroxine: a serum abnormality due to increased affinity of iodothyronines for serum binding protein. Lancet 1979;: $639-42$

9 Lee WNP, Golden MP, Van Herle AJ, et al. Inherited abnormal thyroid hormone binding protein causing selective increase of total serum thyroxine. J Clin Endocrinol Metab 1979;49:292-9.

10 Croxson MS, Palmer BN, Holdaway IM, et al. Detection of familial dysalbuminaemic hyperthyroxinaemia. BMJ (Clin Res Ed) 1985;290: 1099-102

11 Benvenga S. Familial dysalbuminaemic hyperthyroxinaemia and other causes of euthyroid hyperthyroxinaemia. J R Soc Med 1988;81:556-7.

12 Petersen CE, Scottolini AG, Cody LR, et al. A point mutation in the human serum albumin gene results in familial dysalbuminaemic hyperthyroxinaemia. J Med Genet 1994;31:355-9. 